\title{
KARAKTERISTIK KIMIA DAN ORGANOLEPTIK PERMEN JELLY LABU SIAM (Sechium edule (Jac.q) Sw.) DENGAN VARIASI KONSENTRASI AGAR-GELATIN
}

\author{
Chemical and Organoleptic Properties of Chayote Jelly Candy (Sechum edule (Jac.q) Sw.) \\ With The Variation of Agar-Gelatin Concentration
}

\author{
Bambang Setyawan, Akhmad Mustofa, Yustina Wuri Wulandari \\ Fakultas Teknologi dan Industri Pangan Universitas Slamet Riyadi Surakarta \\ Jl. Sumpah Pemuda 18 Joglo Kadipiro Surakarta 57136 \\ Email: bambangunisri@gmail.com
}

\begin{abstract}
ABSTRAK
Labu siam mengandung mineral, sedikit gula dan air. Selain itu labu siam juga mengandung zat antioksidan seperti flavanoid dan vitamin C yang baik untuk menangkal radikal bebas dan mencegah kanker. Tekstur permen jelly sangat tergantung pada bahan pembentuk gel serta komponennya. Penelitian ini bertujuan untuk mengetahui formulasi terbaik antara konsentrasi ekstrak labu siam, variasi agar-gelatin yang menghasilkan permen jelly dengan aktivitas antioksidan yang tinggi serta kadar gula yang rendah dan disukai konsumen.

Penelitian ini menggunakan Rancangan Acak Lengkap (RAL) faktorial dengan dua faktor. Faktor 1 adalah ekstrak labu siam 5, 10, dan $15 \mathrm{~g}$ serta faktor 2 adalah variasi agar-gelatin 2,5g+37,5g, 5g+35g, 7,5g+32,5g. Hasil penelitian menunjukkan bahwa perlakuan terbaik adalah perlakuan ekstrak labu siam $15 \mathrm{~g}$ dan variasi agar-gelatin 7,5g+32,5g yang menghasilkan permen jelly dengan kadar air 18,6\%, kadar abu 2,76\% kadar gula reduksi o,55\% dan aktivitas antioksidan $8,64 \%$, warna kuning muda $(2,06)$, rasa manis $(2,26)$, tingkat kekenyalan $(1,66)$, dan disukai $(2,46)$.
\end{abstract}

Kata kunci : Labu siam, agar, gelatin, permen jelly.

\begin{abstract}
Chayote contain mineral, less sugar and water. Chayote also contains antioxidant such as flavanoid and vitamin $C$ which effective to counteracting free radicals and prevent cancer. Jelly candy's texture depend on the ingredients that forming the gel and its component. The purpose of this research was to determined the best formulation between the concentration of chayote extract and variation of gel-gelatin which produce jelly candy with low level of sugar, high level of antioxidant and favored by the consumers.

This research using Completely Randomized Design (CDR) factorial with two factors. The first factor was chayote extract e.i 5, 10, and $10 \mathrm{~g}$. The second factor was variation of the gel-gelatin e.i $2.5 \mathrm{~g}+37.5 \mathrm{~g}, 5 \mathrm{~g}+35 \mathrm{~g}$, $7.5+32.5 \mathrm{~g}$. The result of this research showed that the best treatment jelly candy with $15 \mathrm{~g}$ chayote extract and $7.5 \mathrm{~g}+32.5 \mathrm{~g}$ gel-gelatin variation. This treatment produce jelly candy that contains $18.6 \%$ of water $2.76 \%$ of ash, $0.55 \%$ of reducing sugar content, and 8.64\% antioxidant activity, (2.26) light yellow, (2.26) sweet taste, (2.26) texture, and (2.46) preferred.
\end{abstract}

Keywords : Chayote, agar, gelatin, jelly candy.

Jurnal Teknologi dan Industri Pangan 4 (1): 22-26 


\section{PENDAHULUAN}

Labu siam mengandung beberapa komponen yang dapat dimanfaatkan sebagai obat di antaranya: saponin, flavanoid, vitamin A, thiamin, protein dan masih banyak lagi kandungannya (Saade, 1996). Meskipun kandungan dan manfaat labu siam sangat banyak namun mayoritas masyarakat Indonesia kurang meminati untuk mengkonsumsi ataupun mengolahnya. Perlu dilakukan inovasi produk labu siam untuk meningkatkan harga jual dan digemari masyarakat Indonesia salah satunya diolah menjadi permen jelly.

Permen adalah makanan berkalori tinggi yang pada umumnya berbahan dasar gula, air, dan sirup fruktosa. Kadar gula dalam permen biasanya tinggi, sehingga dapat menyebabkan gigi berlubang. Definisi permen lunak menurut SNI 3547-2-2008 adalah makanan selingan berbentuk padat, dibuat dari gula atau campuran gula dengan pemanis lain, dengan atau tanpa penambahan bahan pangan lain dan bahan tambahan pangan (BTP) yang diijinkan, bertekstur relatif lunak atau menjadi lunak jika dikunyah. Melihat manfaat labu siam yang memiliki nutrisi yang baik bagi kesehatan, dan stevia sebagai produk produk alami pengganti gula, maka perlu diteliti pembuatan permen jelly labu siam dengan penambahan stevia sebagai pemanis dan variasi konsentrasi agar-agar sehingga diperoleh permen jelly labu siam yang bermanfaat bagi kesehatan. Tujuan penelitian ini untuk mengetahui formulasi terbaik antara konsentrasi ekstrak labu siam, variasi agargelatin yang menghasilkan permen jelly dengan aktivitas antioksidan yang tinggi serta kadar gula rendah serta mengetahui karakteristik permen jelly yang disukai konsumen.

\section{METODE PENELITIAN}

\section{Alat dan Bahan Penelitian}

Alat yang digunakan adalah alat timbangan, gelas ukur, vortex, spektofotometri genesys $10 \mathrm{~s}$ UV-VIs, alat destilasi kadar air, tabung reaksi pyrex, muffle, kurs, oven memmerth, water bath, peralatan pembantu dan almari pendingin.

Bahan yang digunakan dalam penelitian yaitu labu siam, agar, gelatin, asam sitrat, glukosa, stevia, aquades, xylen, reagen arsen, reagen Nelson, dan DPPH.

\section{Rancangan Percobaan}

Penelitian ini menggunakan Rancangan Acak Lengkap (RAL) faktorial yang terdiri dari dua faktor. Faktor pertama ekstrak labu siam $(5,10,15 \mathrm{~g})$ dan faktor kedua variasi agar-gelatin $(2,5 \mathrm{~g}+37,5 \mathrm{~g}, 5 \mathrm{~g}+35 \mathrm{~g}, 7,5 \mathrm{~g}+32,5 \mathrm{~g})$. Berdasarkan desain penelitian maka diperoleh 9 kombinasi perlakuan masing-masing perlakuan diulang sebanyak dua kali. Data yang diperoleh dianalisis dengan uji sidik ragam pada jenjang nyata 0,05. Jika ada beda nyata dilanjutkan Uji Tukey untuk mengetahui beda nyata antar perlakuan pada tingkat signifikasi $5 \%$.

\section{CARA PENELITIAN}

\section{Pembuatan Ekstrak Labu Siam}

Labu siam disortasi lalu dicuci, dikupas, dipotong kemudian dijuicer dan ditambahkan aquades untuk mendapatkan ekstrak labu siam.

\section{Pembuatan Permen Jelly Labu Siam}

(Riyawan et al., 2016) yang telah

\section{dimodifikasi}

Air sebanyak $100 \mathrm{ml}$ direbus dan ditambahkan ekstrak labu siam sesuai perlakuan $(5,10,15 \mathrm{~g})$. Kemudian ditambahkan gula stevia dan diaduk perlahan sampai larut, ditambahkan agar dan gelatin diaduk agar tidak menggumpal, dimasukkan glukosa dan asam sitrat. Setelah tercampur dimasukkan ke loyang tunggu 1 jam dan dimasukkan ke almari pendingin.

\section{CARA PENGUMPULAN DATA}

Analisis yang dilakukan dalam penelitian ini yaitu analisis kimia dan orgonoleptik. Analisis kimia terdiri dari uji kadar air dengan metode destilasi (Sudarmadji et al., 1997), analisis kadar abu dengan metode thermogravimetri (Sudarmadji et al., 1997), analisis aktivitas antioksidan dengan metode DPPH (Fajriani, 2013), analisis kadar gula reduksi dengan metode Nelson Somogyi (Sudarmadji et al., 1997) dan uji organoleptik dengan metode scoring test (Utami, 1992) meliputi uji warna, rasa manis, tekstur, dan kesukaan keseluruhan. 
HASIL DAN PEMBAHASAN

Tabel 1. Rangkuman Purata Hasil Analisis Permen Jelly Labu Siam

\begin{tabular}{|c|c|c|c|c|c|}
\hline $\begin{array}{c}\text { Ekstrak } \\
\text { Labu Siam }\end{array}$ & $\begin{array}{c}\text { Variasi Agar- } \\
\text { gelatin }\end{array}$ & Kadar Air & Kadar Abu & Gula Reduksi & Antioksidan \\
\hline \multirow{3}{*}{$5 g$} & \multirow{3}{*}{$2,5 g+37,5 g$} & $11,25^{\mathrm{a}}$ & $1,26^{\mathrm{a}}$ & $0,48^{a}$ & $2,37^{\mathrm{a}}$ \\
\hline & & $11,58^{a}$ & $1,39^{\mathrm{a}}$ & $0,49^{\mathrm{a}}$ & $2,5 \mathrm{O}^{\mathrm{a}}$ \\
\hline & & $12,38^{a}$ & $1,62^{\mathrm{a}}$ & $0,50^{a}$ & $4,11^{\mathrm{bc}}$ \\
\hline \multirow{3}{*}{$\log$} & \multirow{3}{*}{$5 g+35 g$} & $11,54^{a}$ & $1,55^{\mathrm{a}}$ & $0,49^{a}$ & $4,57^{\mathrm{ab}}$ \\
\hline & & $13,82^{a}$ & $1,64^{\mathrm{ab}}$ & $0,5 \mathrm{O}^{\mathrm{a}}$ & $4,87^{\mathrm{ab}}$ \\
\hline & & $15,02^{\mathrm{ab}}$ & $2,18^{\mathrm{bc}}$ & $0,5^{\mathrm{ab}}$ & $5,50^{\mathrm{b}}$ \\
\hline \multirow{3}{*}{$15 \mathrm{~g}$} & \multirow{3}{*}{$7,5 g+32,5 g$} & $14,39^{\mathrm{ab}}$ & $2,29^{\mathrm{cd}}$ & $0,51^{a b}$ & $4,44^{\mathrm{ab}}$ \\
\hline & & $15,50^{\mathrm{ab}}$ & $2,48^{\mathrm{cd}}$ & $0,52^{\mathrm{ab}}$ & $6,77^{\mathrm{bc}}$ \\
\hline & & $18,67^{\mathrm{b}}$ & $2,7^{6 \mathrm{~d}}$ & $0,55^{\mathrm{b}}$ & $8,64^{\mathrm{c}}$ \\
\hline
\end{tabular}

Keterangan: Angka yang diikuti huruf yang berbeda menunjukkan berbeda nyata dengan uji Tukey $5 \%$.

\section{Kadar Air Permen Jelly Labu Siam}

Tabel 1 menunjukkan bahwa kadar air tertinggi adalah $18,67 \%$ dihasilkan pada perlakuan ekstrak labu siam $15 \mathrm{~g}$ dan variasi agargelatin 7,5g+32,5g, sedangkan kadar air terendah adalah $11,25 \%$ dihasilkan pada perlakuan ekstrak labu siam $5 \mathrm{~g}$ dan penambahan variasi agargelatin $2,5 \mathrm{~g}+37,5 \mathrm{~g}$. Semakin tinggi jumlah atau konsentrasi gelatin dan agar maka semakin tinggi kadar air. Hal ini karena semakin banyak jumlah gelatin yang ditambahkan dalam pembuatan permen jelly maka molekul-molekul yang saling bertautan semakin banyak pula, sehingga air yang berada dalam molekul gelatin jumlahnya lebih banyak daripada air yang menguap saat pemasakan (Herutami, 2002).

\section{Kadar Abu Permen Jelly Labu Siam}

Tabel 1 menunjukkan bahwa kadar abu tertinggi adalah 2,76\% dihasilkan pada perlakuan ekstrak labu siam $15 \mathrm{~g}$ dan variasi agar+gelatin 7,5g+32,5g, sedangkan kadar abu terendah adalah 1,26\% dihasilkan pada perlakuan ekstrak labu siam $5 \mathrm{~g}$ dan penambahan variasi agar-gelatin $2,59+37,5$ g. Semakin tinggi ekstrak labu siam dan variasi agar-gelatin maka semakin tinggi pula kadar abu permen jelly. Hal ini karena ekstrak labu siam yang mengandung cukup banyak mineral seperti mangan, seng, kalsium, magnesium dan fosfor. Kadar abu yang semakin meningkat juga dikarenakan adanya gelatin yang dalam setiap perlakuan. Hal ini karena gelatin mengandung mineral $2-4 \%$ (Hastuti dan Sumpe, 2007), sehingga semakin banyak konsentrasi yang ditambahkan semakin tinggi kadar abu permen jelly.

\section{Kadar Gula Reduksi Permen Jelly Labu}

\section{Siam}

Tabel 1 menunjukkan kadar gula reduksi tertinggi adalah o,55\% dihasilkan pada perlakuan ekstrak labu siam $15 \mathrm{~g}$ dan variasi agar-gelatin 7,5g+32,5g sedangkan kadar gula reduksi terendah adalah o,48\% dihasilkan pada perlakuan ekstrak labu siam $5 \mathrm{~g}$ dan penambahan variasi agar-gelatin $2,5 \mathrm{~g}+37,5 \mathrm{~g}$. Semakin tinggi penambahan variasi agar dan gelatin tidak merubah kandungan gula reduksinya. Hal ini sesuai dengan penelitian (Nurismanto et al., 2015) yang menyatakan bahwa gelatin tidak mempengaruhi gula reduksi, karena bahan pembuatan gelatin tidak mengandung senyawa yang dapat mereduksi gula. Kadar gula reduksi semakin naik dengan penambahan ekstrak labu siam. Hal ini karena labu siam mengandung gula 1,85\% (Prahasta, 2009).

\section{Aktivitas Antioksidan}

Tabel 1 menunjukkan bahwa aktivitas antioksidan tertinggi pada permen jelly labu siam yaitu sebesar 8,64\% RSA DPPH diperoleh dari perlakuan $15 \mathrm{~g}$ ekstrak labu siam dan $7,5 \mathrm{~g}+32,5 \mathrm{~g}$ variasi agar-gelatin. Aktivitas antioksidan terendah sebesar 2,37\% RSA DPPH diperoleh dari perlakuan $5 \mathrm{~g}$ ekstrak labu siam dan $2,5 \mathrm{~g}+37,5 \mathrm{~g}$ variasi agar-gelatin. Aktivitas antioksidan cenderung meningkat dengan meningkatnya konsentrasi ekstrak labu siam. Hal ini sesuai dengan penelitian (Aini, 2014), menyatakan bahwa ekstrak etanol buah labu 
siam mengandung senyawa yang memiliki aktivitas antioksidan, di antaranya flavanoid, alkaloid, dan saponin. Semakin tinggi ekstrak labu siam maka semakin tinggi kandungan antioksidanya. Hal ini karena ekstrak labu siam mengandung cukup banyak senyawa antioksidan. Senyawa antioksidan tersebut yaitu flavanoid $0,95 \%$, saponin 1,65\%, dan alkaloid $1,57 \%$ (Saade, 1996).

\section{Uji Organoleptik Permen Jelly Labu Siam}

Tabel 2. Purata Hasil Uji Organoleptik Permen Jelly Labu Siam

\begin{tabular}{|c|c|c|c|c|c|}
\hline $\begin{array}{c}\text { Ekstrak } \\
\text { Labu Siam }\end{array}$ & $\begin{array}{c}\text { Variasi } \\
\text { Agar-gelatin }\end{array}$ & Warna & Rasa Manis & Kekenyalan & $\begin{array}{c}\text { Kesukaan } \\
\text { Keseluruhan }\end{array}$ \\
\hline \multirow{3}{*}{$5 g$} & \multirow{3}{*}{$2,5 g+37,5 \mathrm{~g}$} & $2,00^{\mathrm{a}}$ & $1,66^{\mathrm{a}}$ & $2,20^{a}$ & $2,00^{a}$ \\
\hline & & $1,53^{\mathrm{a}}$ & $1,73^{\mathrm{a}}$ & $2,26^{\mathrm{ab}}$ & $2,26^{\mathrm{a}}$ \\
\hline & & $1,80^{a}$ & $1,86^{\mathrm{a}}$ & $2,20^{\mathrm{a}}$ & $2,00^{\mathrm{a}}$ \\
\hline \multirow{3}{*}{$10 g$} & \multirow{3}{*}{$5 g+35 g$} & $1,80^{a}$ & $1,80^{a}$ & $2,73^{\mathrm{ab}}$ & $2,46^{a}$ \\
\hline & & $2,00^{\mathrm{a}}$ & $1,86^{\mathrm{a}}$ & $2,46^{\mathrm{ab}}$ & $2,26^{a}$ \\
\hline & & $2,26^{\mathrm{a}}$ & $1,86^{\mathrm{a}}$ & $2,4 \mathrm{O}^{\mathrm{ab}}$ & $2,33^{\mathrm{a}}$ \\
\hline \multirow{3}{*}{$15 \mathrm{~g}$} & \multirow{3}{*}{$7,5 \mathrm{~g}+32,5 \mathrm{~g}$} & $2,21^{\mathrm{a}}$ & $1,85^{\mathrm{a}}$ & $3,42^{b}$ & $2,07^{\mathrm{a}}$ \\
\hline & & $1,81^{\mathrm{a}}$ & $2,00^{\mathrm{a}}$ & $2,18^{a}$ & $2,25^{\mathrm{a}}$ \\
\hline & & $2,06^{\mathrm{a}}$ & $2,26^{a}$ & $1,66^{\mathrm{a}}$ & $2,46^{\mathrm{a}}$ \\
\hline
\end{tabular}

Hasil dari pengujian organoleptik sebagai berikut :

\section{Warna}

Tabel 2 menunjukkan bahwa beberapa perlakuan tidak menunjukkan perubahan warna yang berbeda pada permen jelly yang dihasilkan. Hal ini karena labu siam memiliki warna yang sama saat dilakukan sortasi pada pengolahan sehingga warna tidak begitu berbeda nyata. Selain itu karena labu siam hanya memberi sedikit warna hijau muda. Hasil penelitian menunjukkan bahwa perlakuan konsentrasi ekstrak labu siam $5 g$ dan variasi agar-gelatin 5g+35g menghasilkan permen jelly labu siam dengan warna kekuningan $(1,53)$, pada perlakuan konsentrasi ekstrak labu siam $10 g$ dan variasi agar-gelatin 7,5g+32,5g menghasilkan permen jelly labu siam dengan warna kekuningan $(2,26)$.

\section{Rasa Manis}

Tabel 2 menunjukkan bahwa perlakuan ekstrak labu siam $15 \mathrm{~g}$ dan variasi agar-gelatin $7,5 \mathrm{~g}+32,5 \mathrm{~g}$ menghasilkan permen jelly dengan rasa manis $(2,26)$ sedangkan perlakuan ekstrak labu siam $5 \mathrm{~g}$ dan variasi agar-gelatin $2,5 \mathrm{~g}+37,5 \mathrm{~g}$ menghasilkan permen jelly yang kurang manis yaitu $(1,66)$.

\section{Kekenyalan}

Tabel 2 menunjukkan bahwa perlakuan konsentrasi ekstrak labu siam 15 g dan variasi agar-gelatin $7,5 \mathrm{~g}+32,5 \mathrm{~g}$ menghasilkan permen jelly labu siam dengan tingkat kekenyalan $(1,66)$. Pada perlakuan konsentrasi ekstrak labu siam $15 \mathrm{~g}$ dan variasi agar-gelatin $2,5 \mathrm{~g}+37,5 \mathrm{~g}$ menghasilkan permen jelly labu siam dengan kekenyalan $(3,42)$. Variasi agar-gelatin mempengaruhi sifat kenyal permen jelly yang dihasilkan, penambahan variasi agar memberi sifat lunak dengan tekstur kenyal dan tidak rapuh atau mudah patah.

\section{Kesukaan Keseluruhan}

Pada Tabel 2 hasil uji organoleptik permen jelly yang agak disukai panelis adalah $(2,46)$ yaitu penambahan ekstrak labu siam $10 g$ variasi agar-gelatin 2,5g+37,5g dan ekstrak labu siam $15 \mathrm{~g}$ variasi agar-gelatin $7,5 \mathrm{~g}+32,5 \mathrm{~g}$. Ada dua tabel memiliki nilai yang sama. Hal ini karena rasa permen jelly memiliki rasa manis yang relatif sama dan panelis belum terbiasa dengan rasa labu siam yang diolah menjadi produk permen jelly.

\section{KESIMPULAN}

Konsentrasi ekstrak labu siam dan variasi agar yang optimal dalam pembuatan permen jelly labu siam adalah konsentrasi ekstrak labu siam $15 \mathrm{~g}$ dan variasi agar-gelatin $7,5 \mathrm{~g}+32,5 \mathrm{~g}$. Permen jelly yang dihasilkan mempunyai kadar air $18,60 \%$, kadar abu 2,76\%, kadar gula reduksi o,55\%, aktivitas antioksidan $8,64 \%$, warna 
kuning $(2,06)$, rasa agak manis $(2,26)$, tingkat kenyal dengan skor $(1,66)$, dan disukai $(2,46)$ Kadar gula reduksi terendah berkisar 0,480-55\% dan aktivitas antioksidan permen jelly labu siam dengan variasi agar berkisar antara 8,27-8,64\% RSA DPPH. Semakin banyak konsentrasi labu siam dan variasi agar-gelatin, .semakin tinggi kandungan antioksidanya

\section{DAFTAR PUSTAKA}

Aini, K., 2014. Skrining Fitokimia dan Penentuan Aktivitas Antioksidan serta kandungan Total Fenol Ekstrak Buah Labu Siam (Sechium edule (Jacq. Sw.). Skripsi. Malang: Universitas Negeri Malang.

Fajriani, Q. H., 2013. Penentuan Aktivitas Antioksidan Kulit Buah Naga Super Merah (Hylocereus costaricensis) dan Produk Olahanya berupa Permen Jelly. Skripsi. Bandung: Pendidikan Kimia. Universitas Pendidikan Indonesia.

Hastuti, D., dan Sumpe, I., 2007. Pengenalan dan Proses Pembuatan Gelatin. Jurnal Ilmu - Ilmu Pertanian. 3. (1): 39-48.

Herutami, R. 2002. Aplikasi Gelatin Tipe
A dalam Pembuatan permen jelly Mangga (Mangifera indica L). Skripsi. Bogor: Fakultas Teknologi Pertanian. Institut Pertanian Bogor.

Nurismanto, R., Sudaryati, dan Ihsan, H, A. 2015. Konsentrasi Gelatin Dan Karagenan Pada Pembuatan Permen Jelly Sari Brokoli (Brassica Oleracea). Jurnal Rekapangan, 9 (2): 1-4.

Prahasta, A., 2009. Agibisnis Labu Siam. Bandung: Pustaka Gafika.

Riyawan, F., Mustofa, A., Kurniawati, L., 2016. Aktivitas Antioksidan Permen Jelly dengan Variasi Konsentrasi Ekstrak Kayu Secang (Caesalpinia sappan L.) dan Lama Ekstraksi. Jitipari. 1 (9): 1-5. Surakarta: Universitas Slamet Riyadi Saade., R. L., 1996. Chayote Sechiumedule (jacq.) Sw. Germany: International Plant Genetic Resources Institute.

Sudarmadji, S., Haryono, B., dan Suhardi., 1997. Prosedur Analisa Bahan Makanan dan Pertanian. Yogyakarta: Liberty.

Utami, I. S., 1992. Uji Inderawi: Evaluasi Sifat, Tekstur, Warna, Profit Sensoris. Yogyakarta: PAU Pangan Gizi. Universitas Gadjah Mada. 